Portland State University

PDXScholar

Spring 2021

\title{
Quantifying Biotic VOC Emissions from Moss: Air Quality Impacts of Isoprene and Monoterpenes in Urban Environments
}

Danlyn L. Brennan

Portland State University

Follow this and additional works at: https://pdxscholar.library.pdx.edu/honorstheses

Part of the Physics Commons

Let us know how access to this document benefits you.

Recommended Citation

Brennan, Danlyn L., "Quantifying Biotic VOC Emissions from Moss: Air Quality Impacts of Isoprene and Monoterpenes in Urban Environments" (2021). University Honors Theses. Paper 1118.

https://doi.org/10.15760/honors.1149

This Thesis is brought to you for free and open access. It has been accepted for inclusion in University Honors Theses by an authorized administrator of PDXScholar. Please contact us if we can make this document more accessible: pdxscholar@pdx.edu. 


\title{
Quantifying Biotic VOC Emissions from Moss:
}

Air quality impacts of isoprene and monoterpenes in urban environments

\author{
By \\ Danlyn L. Brennan \\ An undergraduate honors thesis submitted to in partial fulfillment of the \\ requirements for the degree of \\ Bachelor of Science
}

in

Biomedical Physics

Thesis Advisor

Olyssa Starry, $\mathrm{PhD}$

Portland State University

2021 


\section{Quantifying Biotic VOC Emissions from Moss}

Air quality impacts of isoprene and monoterpenes in urban environments

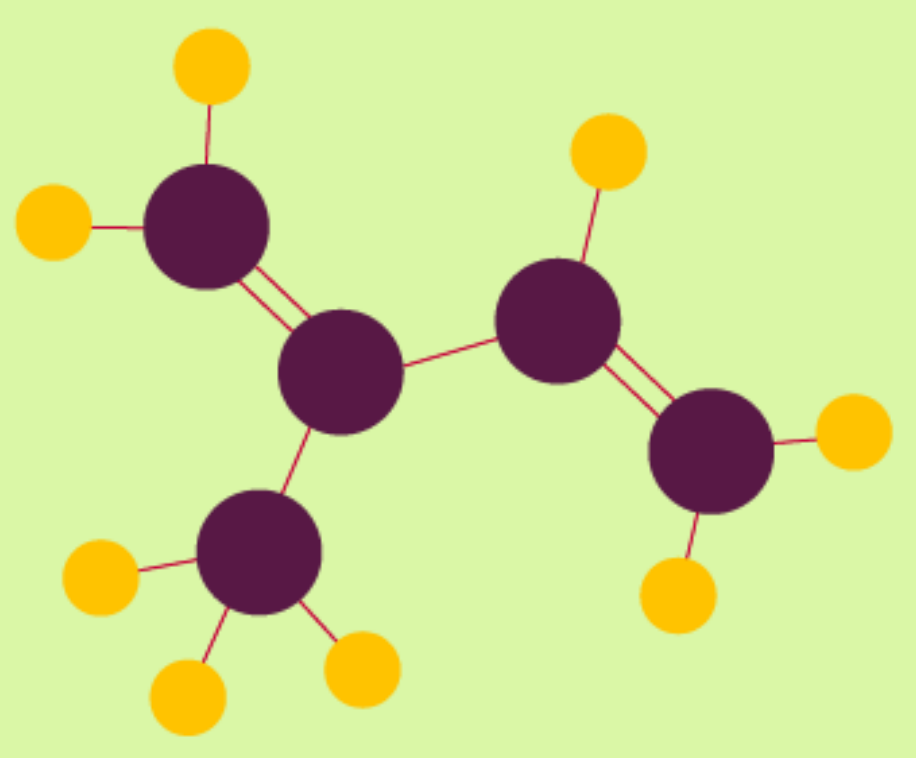

\section{Danlyn L. Brennan}

06.11 .2021

The University Honors College

Departmental Advisor: Olyssa Starry, PhD 


\section{ABSTRACT}

Plant derived biogenic volatile organic compound (VOC) emissions contribute to secondary emissions of molecules such as ground level ozone $\left(\mathrm{O}_{3}\right)$ and PM 2.5 which are known to be harmful to the environment and negatively impact human health. Currently, most known biogenic VOC emissions are from vascular plants like trees and economically significant crops. Air quality models use known emission rates from these measurements and have many unknown sources yet to identify. Unknown values of emissions occur due to a lack of measurements of a wider variety of plants, especially that of smaller and lesser studied species of bryophytes; mosses. This experiment aimed to provide previously unmeasured flux values of isoprene and monoterpenes from four common moss species; Antitrichia californica, Dicranoweisia cirrata, Polytrichum juniperinum, and Racomitrium canescens. Fluxes of isoprene between species were shown to vary significantly while monoterpenes had similar flux values across species. Isoprene flux of $P$. juniperinum was significantly higher, $656.80 \pm$ $335.0\left(\mu \mathrm{g} / \mathrm{h} / \mathrm{m}^{2} \pm \mathrm{SD}\right)$, than the other three species and would not be recommended for purposeful cultivation on green infrastructure like ecoroofs. 


\section{INTRODUCTION}

The air we breathe consists of a myriad of gases and small particles; much of which is necessary for sustaining life (Fehsenfeld et al., 1992). Identifying airborne compounds and how much is exchanged between the biosphere and atmosphere can provide us a lot of information to help answer many questions important to a broad range of disciplines within the scientific community but also to society as a whole (J. Lin et al., 2019). One of the most pressing challenges we face, climate change, necessitates the development of methods to identify new sources of biogenic volatile organic compounds (VOCs), like isoprene and monoterpenes from plants (Guenther et al., 2012; Hidalgo et al., 2008; Fehsenfeld et al., 1992; daSilva et al., 2018; Ghirardo et al., 2016 ). Approximately 1 billion metric tons of carbon in the form of non-methane VOCs are emitted into the atmosphere each year (Fehsenfeld et al., 1992; A. Arneth et al., 2008).

Isoprene and monoterpenes are only two of the many non-methane VOCs that drive global tropospheric chemistry and are major players in the global carbon cycle. The greatest anthropogenic sources of these hydrocarbons come from the combustion of fossil fuel, industrial processes, and wastes (Hidalgo et al., 2008). In addition to the emissions from human activities, natural processes such as biomass decomposition, seasonal fluctuations, and temperature dependent metabolism contribute to the total flux of hydrocarbons as VOCs into the atmosphere (Fehsenfeld et al., 1992; Pio et al. 1994; Guenther et al., 2012). 
About half of all of those emissions are two molecules that play a key role in formation of air pollutants; isoprene (2-methyl-1,3-butadiene, $\mathrm{C}_{5} \mathrm{H}_{8}$ ) and monoterpenes (large group of diverse molecules comprised of two isoprene units) (Fehsenfeld et al., 1992; Guenther et al., 2006; Sharkey et al. 2008). These VOCs contribute to the formation of hazardous air pollution like secondary organic aerosols (SOA) and ground level ozone $\left(\mathrm{O}_{3}\right)$. This occurs when isoprene and monoterpenes act as reducing agents in photo-oxidative chemical reaction cycles with $\mathrm{NO}$ and $\mathrm{NO}_{2}$ - together known as $\mathrm{NO}_{\mathrm{x}}$ - concentrations and temperature increase (Fehsenfeld et al., 1992). High $\mathrm{NO}_{\mathrm{x}}$ conditions as well as elevated temperatures are often found in densely populated urban areas (DeSilva et al 2018, Ghirardo et al. 2016). Isoprene makes up the largest portion of the hydrocarbon emissions driving many climate models (Fehsenfeld et al., 1992; Guenther et al., 2006, Simon et al., 2019). Most plant based biogenic VOC research efforts focus on isoprene for this reason, however, in some plant species, monoterpenes have been shown to make up the majority of VOC emissions especially from trees in coniferous forests (Arneth et al., 2008; Pio et al. 1998).

Many studies of VOC emissions are of trees and their leaf and resin emissions (Ghirardo et al, 2016; J. Lin, et al. 2019; Niinemets et al., 2010; Pio et al., 1994; Simon et al. 2019). Since monoterpenes make up a significant portion of total VOC emissions it is important to characterize and further identify unknown sources of isoprene and monoterpene fluxes (Arneth et al., 2008; Guenther et al., 2012; J. Lin, et al. 2019). Yet, the atmospheric impacts of plant derived VOC 
emissions are still poorly understood and a large portion of that missing data comes from unknown urban emission sources (Arneth et al., 2008; J. Lin, et al. 2019).

Current environmental engineering efforts to mitigate damages caused by anthropogenic emissions have become increasingly backed by policy makers and city planners yet poor air quality, especially high $\mathrm{PM}_{2.5}$ still contributes to millions of deaths worldwide (MacMullan et al., 2009; Simon et al., 2019). Many of these technologies promoted as "green infrastructure" - street trees, hedges, bioswales, green walls, and ecoroofs - are implemented to meet governmental health-based standards and work towards limiting the impacts of climate change based on the idea that plants remove pollutants and small particles from the air (Hewitt et al., 2020). A common green mitigation strategy that has been widely used and backed by sustainable policy is ecoroofs. In cities such as Portland, Oregon policies like The Central City 2035 Plan (Policy Chapter 6.4 - Green Infrastructure) calls for increasing green infrastructure with ecoroof installations on new buildings. Ecoroofs are typically made up of layers of waterproofing membranes, rock or soil substrate for plants to root into, and a variety of plant species. Ecoroofs have been shown to reduce urban heat island effect and help mitigate damages from storm water runoff by reducing storm surge flows (AK et al., 2018; Chang et al., 2021, MacMullan et al., 2009; Murphy, 2015). Although an ecoroof's potential for pollution mitigation is often quantified by temperature regulation and stormwater management benefits, less is understood about role 
they may play in local air quality (Berardi et al., 2013 ; Ramasubramanian et al., 2021; Scharf \& Zluwa, 2017).

Many recent air quality experiments have investigated common house plants and their capacity to clean indoor air, a hypothesis which has been shown to be overestimated and questionable as a viable option for indoor air pollution reduction (Abbass et al., 2017; Cummings \& Waring, 2020). Few studies have examined VOC emissions from ecoroofs. Common ecoroof plants found in most geographic locations include sedums and mosses. They are attractive options for urban rooftops because they are low growing, aesthetically pleasing, and require low maintenance due to their ability to survive extreme temperatures and drought conditions (AK et al., 2018; Anderson et al., 2010; Beraldi et al., 2019).

There are many physiological differences between sedums and mosses and how they might function within an ecoroof system therefore providing "ecosystem services" like resisting the flow of water runoff from the building into the local water system (AK et al., 2018; Anderson et al., 2010; Beraldi et al., 2019, Schroll et al., 2011). Unlike sedums who take up water with their roots and hold it in their leaves, mosses are non-vascular and absorb their water directly into their cells via osmosis, thus acting like a sponge retaining water upon contact. The waxy cuticle of sedums, however, work well to hold water inside the leaf but aren't holding onto much water over time. This absorbing property of moss has made it particularly interesting to researchers working on plant based stormwater management systems (Anderson et al., 2010; Schroll et al., 2011)). 
Mosses are the most ancient fully terrestrial plant species and one of the most diverse comprising approximately 13,000 different species. Despite their diminutive size, mosses are earth's most phylogenetically basal group of land plants occurring in nearly all terrestrial ecosystems and thriving in some of Earth’s harshest environments. Only a handful of species have been closely studied and uncertainty in VOC emissions exist in their magnitude, variability, response to environmental drivers, metabolic requirements and their interplay with other organisms (Hanson et al., 2009; Rosenstiel et al., 2012; Vicherová et al., 2020). Most early research in VOCs was from vascular plants and that trend persists with surprisingly few empirical studies on VOC emissions from mosses (Hanson et al., 2009; Vicherová et al., 2020).

Observations show that plant emissions can either reduce or increase levels of secondary air pollutants depending on a number of factors, especially that of chemical concentrations of the VOCs present (Hewitt et al., 2020). Although ecoroofs might be designed with the best intentions for mitigating urban pollution, it is important to identify high VOC emitting plant species utilized by green infrastructure like ecoroofs to avoid being an ecosystem disservice by reducing local air quality where reactive $\mathrm{NO}_{\mathrm{x}}$ levels are elevated (Abbass et al., 2017; Cummings et al., 2020; daSilva et al., 2017; Ghirardo et al., 2015; Hewitt et al., 2020). 


\section{RESEARCH QUESTION}

This thesis details a cross-disciplinary experimental method that was developed for characterization of VOC emissions from plants using high-throughput Proton Transfer Reaction - Time of Flight - Mass Spectrometry (PTR-ToF-MS). To quantify the amount of VOCs that might be emitted by ecoroofs, empirical measurements with a PTR-ToF-MS are used to quantify concentrations of VOCs by plant species. Averaging the chemical mass concentrations of isoprene and monoterpenes over time allows for the determination of emissions rates (mass per time - M/T) and fluxes (mass per time per area squared - M/T/A²) (Brenton \& Godfrey, 2010; Materic et al., 2015).

Can this experimental method be used to determine isoprene and monoterpene emissions flux from common rooftop mosses? In order to identify high emitting moss species to avoid growing on ecoroofs, I empirically measured VOC concentrations over time to determine which mosses might contribute to the total flux of isoprene and monoterpene emissions. I predicted that the highest emitting species would be Polytrichum juniperinum protonema based on previous unpublished observations of elevated isoprene emissions measured with Reduced Gas Detector (RGD2, Trace Analytical, Menlo Park, CA) (Deakova, 2019). Either $P$. juniperinum is an unusually high emitter or other mosses are also similar and might be unknown sources of high isoprene fluxes. 


\section{MATERIALS \& METHODS}

For this experiment, field collected patches of moss gametophyte tissue of Antitrichia californica, Dicranoweisia cirrata, Polytrichum juniperinum, and Racomitrium canescens were planted (4 replicates per species) in $100 \mathrm{~g}$ of perlite and peat moss substrate in polypropylene pots (0.1143 m diameter, $0.1016 \mathrm{~m}$ deep). All moss pots were acclimated in a greenhouse with the same ambient temperature and natural day light conditions with daily watering for approximately one month before experimental measurements were collected. A high-throughput dynamic air flow sampling method was used to determine moss VOC emission concentrations over time. The high mass resolution power and sensitivity (> $200 \mathrm{cps} / \mathrm{ppbv}$ ) of a PTR-1000 (IONICON PTR-TOF-MS - Trace VOC Analyzer) was utilized to receive a steady rate of air flow through a custom high throughput "chamber-in-chamber" setup (Fig. 1, Fig. 2), allowing for an efficient and accurate estimate of VOC flux from an array of small biological samples in chambers. Each inner chamber flowed to the PTR-ToF-MS separately with an automated eight port selector. A simplified flow schematic is shown in Fig. 1. 


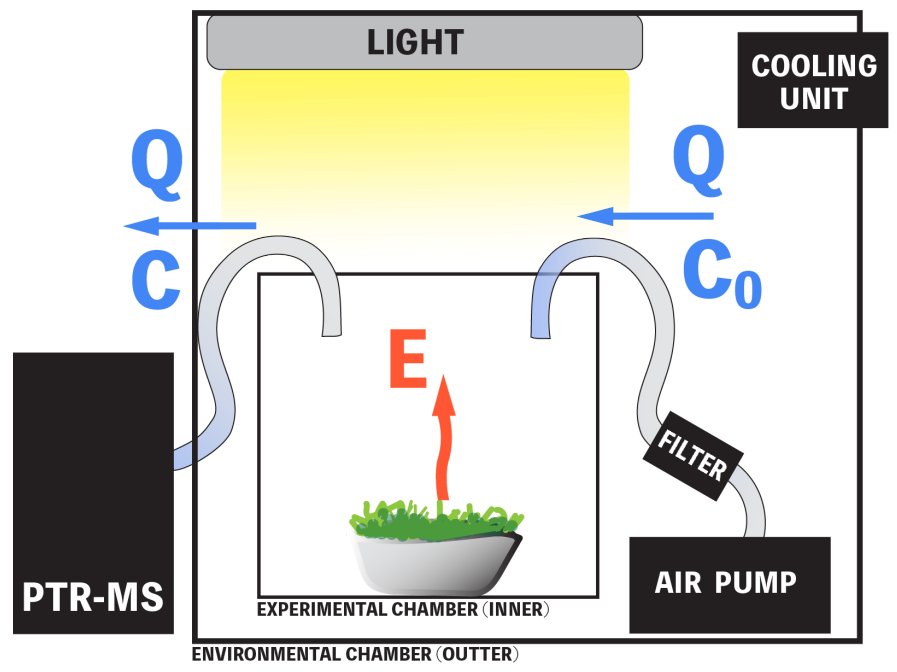

Fig 1. Simplified schematic representation of chamber in chamber air flow system.

\section{EXPERIMENTAL CONDITIONS}

The chamber-in-chamber system consisted of an array of 8 (7" tall and 7" diameter) round clear chambers allowed for sampling 7 pots and 1 empty chamber (background air, $\mathrm{C}_{0}$ ) per set (Fig 2). All 8 inner chambers were exposed to the same controlled light (approx $1000 \mu \mathrm{mol} / \mathrm{s} / \mathrm{m}^{\wedge} 2$ ) and temperature $\left(25^{\circ} \mathrm{C}\right.$ ) as well as ambient $\mathrm{CO}_{2}(\sim 500 \mathrm{ppm})$ and $\mathrm{RH}(<80 \%)$ conditions. Controlled conditions were monitored with three HOBO Micro Station Loggers (model 2H21-002) placed around the perimeter of the eight inner chambers with two on the floor of the chamber and one elevated to the same height as the inner chambers (7"). The average of the three was used to determine the approximate temperature and $\mathrm{RH}$ of the chamber conditions. The ambient $\mathrm{CO}_{2}$ was measured with a $\mathrm{LICOR} \mathrm{CO}_{2}$ gas 
sensor (LI-840A CO $2 / \mathrm{H}_{2} \mathrm{O}$ Gas Analyzer) at the PTR-ToF-MS inlet. The LED lamps produced enough heat to raise the temperature above the target temperature so the air cooling unit was used to keep the temperature stable at $25^{\circ} \mathrm{C}$ for the entirety of the experiment.

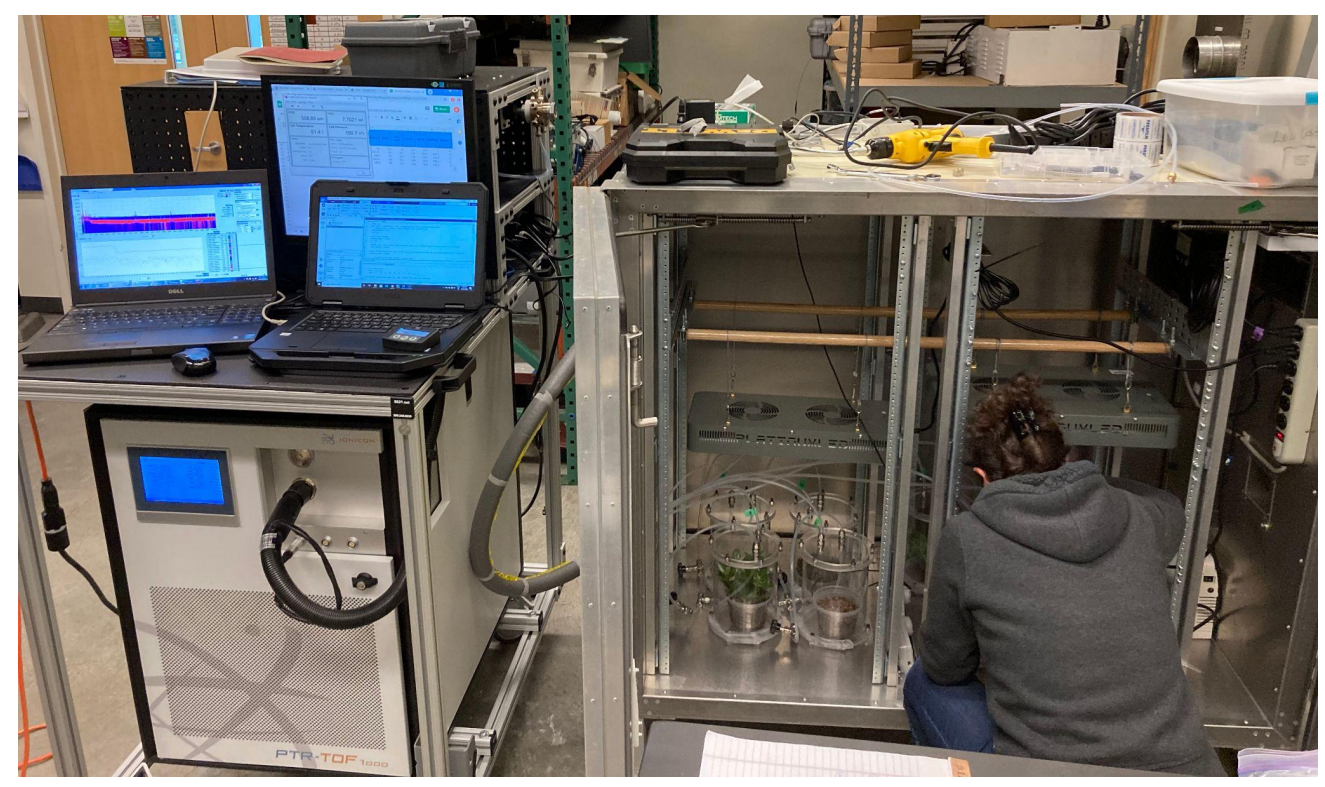

Fig 2. Photo of PTR-ToF-MS attached to "chamber-in-chamber" system.

\section{PROCEDURE}

For these experiments, the PTR-ToF-MS drift tube conditions were set to a multiplier voltage of $600 \mathrm{~V}$, temperature of $60^{\circ} \mathrm{C}$, and 2.2 mbar pressure. The PTR-ToF-MS was operated at an E/N value of 135. Environmental chamber flow sampling lines started at an air pump inside the environmental chamber, where the ambient lab air was pumped through a charcoal filter before reaching the experimental chambers housing the moss. All flow sampling lines were made of 
PFA tubing (1/4"OD, 0.047"ID).

Moss pots were loaded into each of the seven inner chambers and placed below the lamps as close together as possible for even lighting exposure. Chamber conditions were set up and allowed 30 minutes mixing time to reach steady state before commencing the acquisition of data. Flow rates in each chamber were adjusted and recorded. The target flow rate for each chamber was 100 standard cubic centimeters per minute (SCCM).

Each of the moss and substrate samples were scheduled to be measured at the same time of day for consecutive days. We chose the morning and were able to measure 6 moss samples ( 1 empty chamber for background, 1 for just substrate, 6 moss samples) for each set for thirty minutes. Each chamber was sampled for 3 minutes collecting data at 1 cycle/sec. The acquisition data was then saved and ready for mass spectra analysis and spectral peak integration.

\section{ANALYTICAL METHODS}

The data was first analyzed using PTR-MS Viewer V 3.2.8 where a set of spectra peaks are selected for integration and exported as a list of compounds with concentration values in parts per billion (ppb). The mean and standard deviation for each mass's molecular weight (MW) was converted from concentrations in ppb to micrograms per unit volume $\left(\mu \mathrm{g} / \mathrm{m}^{3}\right)$ (Eq. 1). The concentration of isoprene was determined by using the molecular weight (MW = 69.07043) minus one proton $\left(\mathrm{H}^{+}=1 \mathrm{amu}\right)$ for $68.07043 \mathrm{~g} / \mathrm{mol}$. The concentration of monoterpenes was 
determined by summing the masses for $\mathrm{C}_{10} \mathrm{H}_{16}(137.1325 \mathrm{~g} / \mathrm{mol})$ and the fragment $\mathrm{C}_{6} \mathrm{H}_{8}(81.07043 \mathrm{~g} / \mathrm{mol})$ as suggested by analytical method described in similar analyses (Materic et al., 2015).

$$
\frac{\mu g}{m^{3}}=\operatorname{mass} \operatorname{conc}(p p b) \times 12.187 \times M W \times 273.15+\text { temp }\left({ }^{\circ} \mathrm{C}\right)
$$

Assuming constant atmospheric pressure $(\mathrm{P}=1 \mathrm{~atm})$ and temperature $\left(\mathrm{T}=25{ }^{\circ} \mathrm{C}\right)$, the following simplified expression (Eq. 2) can be used.

$$
\frac{\mu g}{m^{3}}=\operatorname{mass} \operatorname{conc}(p p b) \times 24.45 \times M W
$$

To determine the emission rate, the following differential equation is used as the model for mass balance, since the flow rate $Q\left(\mathrm{~m}^{3} / \mathrm{h}\right)$ in Eq. 2 is used to derive the emission rate equation assuming the change in concentration over time is steady where the concentration over time in the chamber volume, $V\left(\mathrm{~m}^{3}\right)$ we can set it equal to zero as shown in Eq. 3.

$$
\begin{aligned}
& V \frac{d C}{d t}=Q\left(C_{0}-C\right)+E \\
& V \frac{d C}{d t}=0 \text { and }\left(Q C_{0}\right)-(Q C)+E=0
\end{aligned}
$$

The amount of air flow per volume is called the air exchange rate, $\lambda\left(\mathrm{h}^{\wedge}-1\right)$ and is used in the simplified expression shown in Eq. 6 for a final emission rate, E ( $\mu \mathrm{g} / \mathrm{h}$ ).

$$
\lambda=\frac{Q}{V}
$$




$$
E=\lambda\left(C_{0}-C\right) V
$$

When normalized by area of the potted moss surface area a flux $\left(\mu \mathrm{g} / \mathrm{h} / \mathrm{m}^{2}\right)$ can be calculated (Eq. 7)

$$
\boldsymbol{\Phi}=\frac{E}{A}
$$

DATA

Table 1 Mean emission rates and flux of moss $(n=4)$ with \pm standard deviation

\begin{tabular}{lcccc}
\hline Species & $\begin{array}{c}\text { Emission rate } \\
\text { Isoprene } \\
(\mu \mathrm{g} / \mathrm{h})\end{array}$ & $\begin{array}{c}\text { Emission rate } \\
\text { Monoterpenes } \\
(\mu \mathrm{g} / \mathrm{h})\end{array}$ & $\begin{array}{c}\text { Emission flux } \\
\text { Isoprene } \\
\left(\mu \mathrm{g} / \mathrm{h} / \mathrm{m}^{2}\right)\end{array}$ & $\begin{array}{c}\text { Emission flux } \\
\text { Monoterpenes } \\
(\mu \mathrm{g} / \mathrm{h})\end{array}$ \\
\hline A. californica & $0.099 \pm 0.41$ & $0.0189 \pm 0.005$ & $9.68 \pm 4.0$ & $1.84 \pm 0.50$ \\
D. cirrata & $0.278 \pm 0.15$ & $0.0208 \pm 0.008$ & $27.09 \pm 14.3$ & $1.87 \pm 1.15$ \\
P. juniperinum & $6.74 \pm 3.44$ & $0.0221 \pm 0.009$ & $656.80 \pm 335.0$ & $2.53 \pm 0.92$ \\
R. canescens & $0.0810 \pm 0.04$ & $0.0197 \pm 0.011$ & $7.86 \pm 4.36$ & $0.60 \pm 0.60$ \\
\hline
\end{tabular}


Table 2 Analysis of variance (ANOVA) in flux of isoprene*

\begin{tabular}{lcccc}
\hline $\begin{array}{c}\text { Source of } \\
\text { Variation }\end{array}$ & $\begin{array}{c}\text { Sum of } \\
\text { Squares }\end{array}$ & $\begin{array}{c}\text { Degrees of } \\
\text { Freedom }\end{array}$ & $\begin{array}{c}\text { Mean } \\
\text { Squares }\end{array}$ & F \\
\hline Within & 337401.76 & 12 & 28116.81 & 14.67 \\
Between & 1237044.08 & 3 & 412348.03 & \\
Total & 1574445.84 & 15 & & \\
\hline
\end{tabular}

$*_{n}=16, k=4,(F(3,12)=14.67, p<0.05)$

Table 3 Analysis of variance (ANOVA) in flux of monoterpenes*

\begin{tabular}{lcccc}
\hline $\begin{array}{c}\text { Source of } \\
\text { Variation }\end{array}$ & $\begin{array}{c}\text { Sum of } \\
\text { Squares }\end{array}$ & $\begin{array}{c}\text { Degrees of } \\
\text { Freedom }\end{array}$ & $\begin{array}{c}\text { Mean } \\
\text { Squares }\end{array}$ & F \\
\hline Within & 9.70 & 12 & 0.809 & 1.10 \\
Between & 2.68 & 3 & 0.893 \\
Total & 12.38 & 15 & \\
$*_{\mathrm{n}=16, \mathrm{k}=4,(\mathrm{~F}(3,12)=0.919, \mathrm{p}<0.05)}$
\end{tabular}



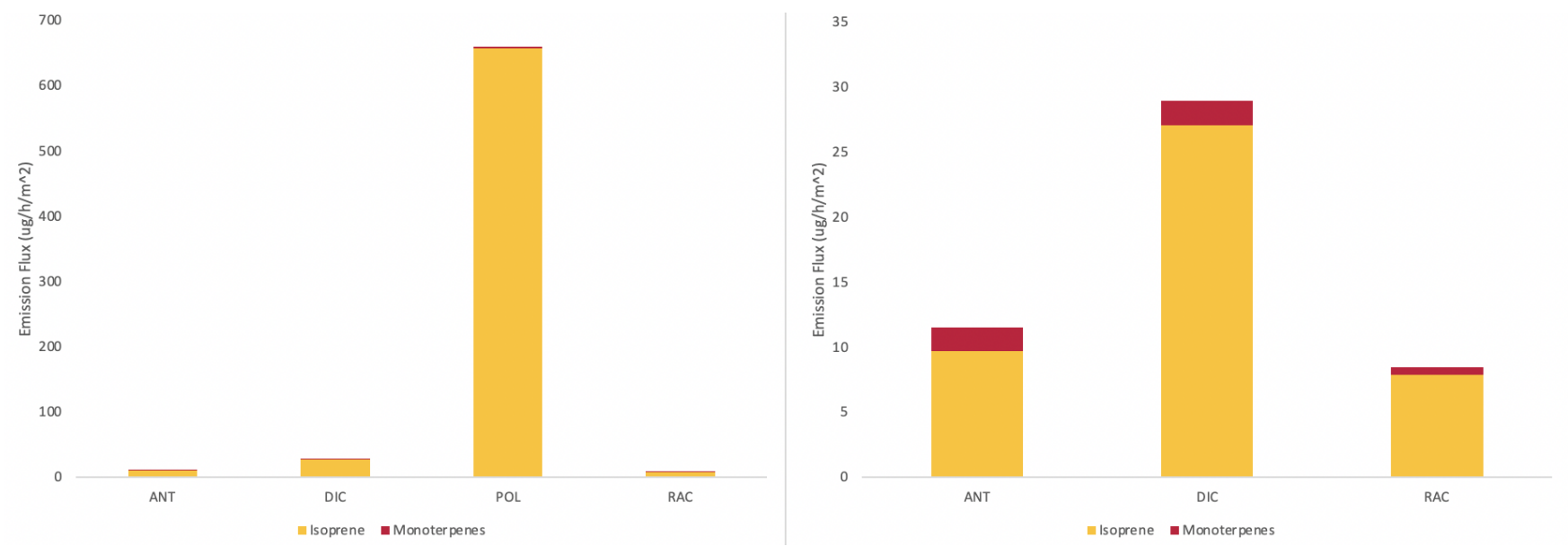

Fig 3. Mean emission flux comparison across species with $P$. juniperinum (L) \& three lower emitting species A. californica, D. cirrata, and R. canescens (R).

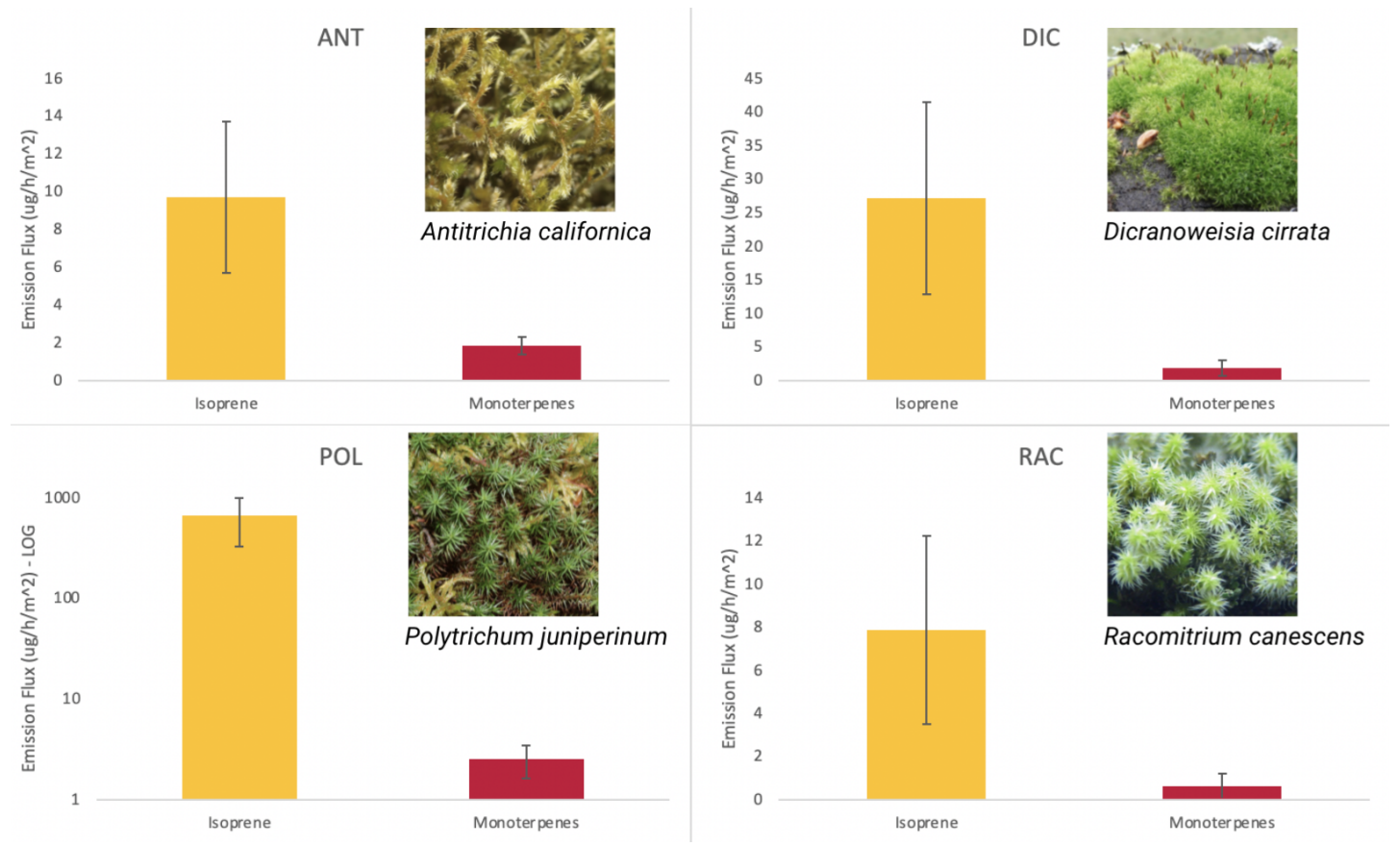

Fig 4. Mean emission flux of isoprene and monoterpenes for four common mosses. Error bars represent the standard deviation $(S D)$ between replicates $(n=4)$. All numerical values can be found in Table 1. 


\section{RESULTS}

Each moss species with 4 replicates each was measured for 3 minutes each. The mean concentrations per cycle (1 sec/1 cycle) for A. californica was $1.50\left(\mu \mathrm{g} / \mathrm{m}^{3}\right)$ for isoprene and $0.283\left(\mu \mathrm{g} / \mathrm{m}^{3}\right)$ for monoterpenes, D. cirrata was $3.85\left(\mu \mathrm{g} / \mathrm{m}^{3}\right)$ for isoprene and $0.271\left(\mu \mathrm{g} / \mathrm{m}^{3}\right)$ for monoterpenes , P. juniperinum was $92.0\left(\mathrm{ug} / \mathrm{m}^{3}\right)$ for isoprene and $0.354\left(\mu \mathrm{g} / \mathrm{m}^{3}\right)$ for monoterpenes, and $R$. canescens was $1.23\left(\mu \mathrm{g} / \mathrm{m}^{3}\right)$ for isoprene and $0.247\left(\mu \mathrm{g} / \mathrm{m}^{3}\right)$ for monoterpenes. Fluxes were determined by normalizing emission rates by surface area of moss pot $\left(0.000095033 \mathrm{~m}^{2}\right)$. Flux comparisons between species can be seen in Fig 3 and Fig 4, yet the overall trend is similar. The most emissive species determined by the experiment was $P$. juniperinum (expected positive control) followed by D. cirrata. $R$. canensens was the least emissive species for isoprene. A one-way ANOVA was conducted to compare variability of the fluxes of isoprene and monoterpenes between the four

species (Table $2 \& 3)$. There was a significant difference in isoprene flux $\left(\mu \mathrm{g} / \mathrm{h} / \mathrm{m}^{2}\right)$ and no significant difference in the flux of monoterpenes between species at the $\mathrm{p}<0.05$ level.

\section{DISCUSSION}

Mosses have been found to offer many ecological benefits as they play a fundamental role in influencing local ecology such as biosphere-atmosphere-hydrosphere communications, physiological and 
evolutionary dynamics, plant-microbe interactions and gametophyte stress-physiology (AK et al., 2018; Anderson et al., 2010; Beraldi et al., 2019; Hanson et al., 2009; Rosenstiel et al., 2012; Vicherová et al., 2020). They are also responsible for providing many ecosystem services in urban environments but the lack of VOC emissions data remains unavailable to air quality models (Lin et al., 2009).

Emissions of isoprene from plants are considered in the low range when they are below 1 ( $\mu \mathrm{g} \mathrm{g} / \mathrm{h} / \mathrm{DW}$ ) (Baraldi et al., 2019). Results from recent studies show isoprene emissions reported in vascular plants like Sedum spectabile with $0.17 \pm$ $0.08(\mu \mathrm{g} / \mathrm{DW} / \mathrm{h})$; mean \pm standard error $(\mathrm{n}=3)$ showing a low emission from (Baraldi et al., 2019). Unpublished data of mean isoprene emission from $P$. juniperinum protonema (immature moss tissue) was observed at a wide range of approximately 1000 to $10,000\left(\mu \mathrm{g} / \mathrm{h} / \mathrm{m}^{2}\right)(\mathrm{n}=244)$ over multiple experiments and treatments including the higher range emissions seen within the nitrogen treatment group (Deakova, 2019). My experiments also show elevated isoprene emission from $P$. juniperinum at a mean of $656.80 \pm 335.0\left(\mu \mathrm{g} / \mathrm{h} / \mathrm{m}^{2} \pm \mathrm{SD}\right)$ but from mature gametophyte moss tissue. This shows that $P$. juniperinum isoprene emission is similar to previous observed values, although differences in tissue type and experimental method vary. My predictions for $P$. juniperinum to be the highest emitter of isoprene was supported while it has similar monoterpene emissions to the other species A. californica, D. cirrata, and $R$. canescens. Comparison of these values suggests that $R$. canescens and $S$. spectabile are the 
lowest emitters, therefore, desirable species choices for green infrastructure.

The lack of available data needed to understand the effects of VOC emissions of mosses is due in large part to the methodological and analytical challenges associated with working with such small yet ubiquitous organisms. That said, even the limited studies investigating VOC emissions from mosses so far have led to significant insights across disciplines including but not limited to genetics, physiology, ecology, and engineering.

Empirical measurements of new emission sources along with sophisticated climate models can be used to explore these questions (Guenther et al., 2006). Other lower- dimensional models such as the one-dimensional coupled canopy-chemistry model (CACHE) and zero-dimensional box models can be utilized for comparing simulation results (Bryan et al., 2012).

Their global influence on numerous global biogeochemical processes, including nitrogen and carbon cycling, appear to be significant (Guenther et al., 2012; Fehsenfeld et al., 1992). Many of the most widely used computational climate models like Model of Emission of Gases and Aerosols from Nature (MEGAN) and ENVI-met simulate potential climate conditions by using outputs generated by complex meteorological and chemical transport/mechanism models like the Weather Research and Forecasting model (WRF-chem), the Regional Atmospheric Chemistry Model (RACM), and the Model of Ozone and Related Chemical Tracers (MOZART), to name a few (Lin et al., 2019). Identifying new biotic sources of 
isoprene and monoterpenes can help us understand the ecological roles and consequences of their emissions. Quantifying VOC emissions from mosses informs an important missing piece of the broader body of knowledge about biosphere-atmosphere interactions.

\section{CONCLUSION}

Isoprene functions as a reducing agent when it interacts with highly reactive background $\mathrm{NO}_{\mathrm{x}}$ to which increases levels of ground level ozone and PM 2.5; thus reducing air quality that has a major impact on public health. Moss on urban green surfaces such as ecoroofs can contribute to isoprene fluxes. Common mosses cover large surface areas and are suggested for installation on green infrastructure for pollution mitigation yet this experimental measurement shows fluxes of isoprene that were previously unknown.

The leading cause of death from environmental pollution is from poor air quality so it is easy to understand the need to engineer spaces that provide an equitable and accessible healthy living experience (Ghirardo et al. 2016; Hewitt et al., 2020). In order to achieve such a goal, work must be done to identify sources and quantify emissions of molecules that have the greatest impact on air quality. Quantifying those unknown emissions of isoprene allows us to identify ways to adjust our environment to lower those emissions (Hewitt et al., 2020).

New species-specific VOCs datasets like these can be incorporated into a variety 
of models to compare and contrast simulated outcomes of ecoroof coverage scenario impacts on urban air quality to better align city planning with goals to improve social, economic, and environmental health. Updated emissions source values within computational models would help hone in on the divers of high risk pollutants like ozone and PM 2.5 in urban areas. Considering the potential for mosses to be effective as a low-cost bio-mitigation option for stormwater management, it is even more pertinent that emissions also be characterized in order to optimize their function by choosing appropriate species. Comparison of isoprene emission values suggests that $R$. canescens and S. spectabile are the lowest emitters which make them appropriate species choices for ecoroofs intended to mitigate, and not further complicate, urban air pollution.

\section{ACKNOWLEDGEMENTS}

This material is based upon work supported by the National Science Foundation under Grant 1605843, and National Institutes of Health Common Fund and Office of Scientific Workforce Diversity under three awards UL1GM118964, RL5GM118963, and TL4GM118965. Views expressed are my own and do not necessarily reflect the views of the National Science Foundation or National Institutes of Health. I would like to extend a special thanks to Dr. Olyssa Starry, Dr. Elliott Gall, Dr. Todd Rosenstiel, and Aurélie Laguerre for assisting and supporting my efforts to measure moss emissions while also providing help with data analysis. I am grateful for the support of the Honors College and Build Exito 


\section{Scholar Program at Portland State University as they offered numerous resources}

to guarantee my success.

\section{REFERENCES}

Abbass, O. A., Sailor, D. J., \& Gall, E. T. (2017). Effectiveness of indoor plants for passive removal of indoor ozone. Building and Environment, 119, 62-70.

AK, M. A., Katoh, Y., Katsurayama, H., Koganei, M., \& Mizunuma, M. (2018). Effects of convection heat transfer on Sunagoke moss green roof: a laboratory study. Energy and Buildings, 158, 1417-1428.

Anderson, M., Lambrinos, J., \& Schroll, E. (2010). The potential value of mosses for stormwater management in urban environments. Urban ecosystems, 13(3), 319-332.

Arneth, A., Monson, R. K., Schurgers, G., Niinemets, Ü., \& Palmer, P. I. (2008). Why are estimates of global isoprene emissions so similar (and why is this not so for monoterpenes)?. Atmospheric Chemistry and Physics Discussions, 8(2), 7017-7050.

Berardi, U., A.H. GhaffarianHoseini, and G. Hoseini. (2013). State-of the-art analysis of the environmental benefits of green roofs. Journal of Applied Energy 115: 411-428.

Baraldi, R., Neri, L., Costa, F., Facini, O., Rapparini, F., \& Carriero, G. (2019). Ecophysiological and micromorphological characterization of green roof vegetation for urban mitigation. Urban Forestry \& Urban Greening, 37, 24-32.

Brenton, A. G., \& Godfrey, A. R. (2010). Accurate mass measurement: terminology and treatment of data. Journal of the American Society for Mass Spectrometry, 21(11), 1821-1835.

Bryan, A. M., Bertman, S. B., Carroll, M. A., Dusanter, S., Edwards, G. D., Forkel, R., ... \& Steiner, A. L. (2012). In-canopy gas-phase chemistry during CABINEX 2009: sensitivity of a 1-D canopy model to vertical mixing and isoprene chemistry. Atmospheric Chemistry and Physics, 12(18), 8829-8849.

Cummings, B. E., \& Waring, M. S. (2020). Potted plants do not improve indoor air quality: a review and analysis of reported VOC removal efficiencies. Journal of exposure science \& environmental epidemiology, 30(2), 253-261.

da Silva, C. M., Corrêa, S. M., \& Arbilla, G. (2018). Isoprene emissions and ozone formation in urban conditions: a case study in the city of Rio de Janeiro. Bulletin of environmental contamination and toxicology, 100(1), 184-188. 
Deakova, T. (2019). Isoprene Emission in Polytrichaceae Mosses. *Ph.D. dissertation

Fehsenfeld, F., Calvert, J., Fall, R., Goldan, P., Guenther, A. B., Hewitt, C. N., ... \& Zimmerman, P. (1992). Emissions of volatile organic compounds from vegetation and the implications for atmospheric chemistry. Global Biogeochemical Cycles, 6(4), 389-430.

Ghirardo, A., Xie, J., Zheng, X., Wang, Y., Grote, R., Block, K., \& Schnitzler, J. P. (2016). Urban stress-induced biogenic VOC emissions and SOA-forming potentials in Beijing. Atmospheric Chemistry and Physics, 16(5), 2901-2920.

Guenther, A. B., Jiang, X., Heald, C. L., Sakulyanontvittaya, T., Duhl, T., Emmons, L. K., \& Wang, X. (2012). The Model of Emissions of Gases and Aerosols from Nature version 2.1 (MEGAN2. 1): an extended and updated framework for modeling biogenic emissions. Geoscientific Model Development, 5(6), 1471-1492.

Hanson, D. T., Swanson, S., Graham, L. E., \& Sharkey, T. D. (1999). Evolutionary significance of isoprene emission from mosses. American Journal of Botany, 86(5), 634-639.

Hewitt, C. N., Ashworth, K., \& MacKenzie, A. R. (2020). Using green infrastructure to improve urban air quality (GI4AQ). Ambio, 49(1), 62-73.

Hidalgo, J., Masson, V., Baklanov, A., Pigeon, G., \& Gimeno, L. (2008). Advances in urban climate modeling. Annals of the New York Academy of Sciences, 1146(1), 354-374.

Lin, J., Kroll, C. N., Nowak, D. J., \& Greenfield, E. J. (2019). A review of urban forest modeling: Implications for management and future research. Urban Forestry \& Urban Greening, 43, 126366.

MacMullan, E., Reich, S., Puttman, T., \& Rodgers, K. (2009). Cost-benefit evaluation of ecoroofs. In Low Impact Development for Urban Ecosystem and Habitat Protection (pp. 1-10).

Materić, D., Lanza, M., Sulzer, P., Herbig, J., Bruhn, D., Turner, C., ... \& Gauci, V. (2015). Monoterpene separation by coupling proton transfer reaction time-of-flight mass spectrometry with fastGC. Analytical and bioanalytical chemistry, 407(25), 7757-7763.

Murphy, S. (2015). Assessing the Effectiveness of Extensive Green Roofs at Improving Environmental Conditions in Atlanta, Georgia.

Niinemets, Ü., Copolovici, L., \& Hüve, K. (2010). High within-canopy variation in isoprene emission potentials in temperate trees: Implications for predicting canopy-scale isoprene fluxes. Journal of Geophysical Research: Biogeosciences, 115(G4).

Pio, C. A. (1998). Atmospheric fluxes and concentrations of monoterpenes in resin-tapped pine forests. Atmospheric Environment, 32(4), 683-691.

Ramasubramanian, P., Luhung, I., Lim, S. B., Schuster, S. C., Starry, O., \& Gall, E. T. (2021). Impact of green and white roofs on air handler filters and indoor ventilation air. Building and Environment, 197, 107860.

Rosenstiel, T. N., Shortlidge, E. E., Melnychenko, A. N., Pankow, J. F., \& Eppley, S. M. (2012). Sex-specific volatile compounds influence microarthropod-mediated fertilization of moss. Nature, 489(7416), 431-433.

Scharf, B., \& Zluwa, I. (2017). Case study investigation of the building physical properties of seven different green roof systems. Energy and buildings, 151, 564-573.

Schroll, E., Lambrinos, J., Righetti, T., \& Sandrock, D. (2011). The role of vegetation in regulating stormwater 
runoff from green roofs in a winter rainfall climate. Ecological engineering, 37(4), 595-600.

Sharkey, T. D., Wiberley, A. E., \& Donohue, A. R. (2008). Isoprene emission from plants: why and how. Annals of botany, 101(1), 5-18

Simon, H., Fallmann, J., Kropp, T., Tost, H., \& Bruse, M. (2019). Urban trees and their impact on local ozone concentration-a microclimate modeling study. Atmosphere, 10(3), 154.

Vicherová, E., Glinwood, R., Hájek, T., Šmilauer, P., \& Ninkovic, V. (2020). Bryophytes can recognize their neighbours through volatile organic compounds. Scientific reports, 10(1), 1-11. 